\title{
"Criar capacidades" para a sensibilidade e a humanização em meio à pandemia de Covid-19: reflexões a partir de Nussbaum e Agamben
}

\author{
"Building capabilities" for sensitivity and humanization amid the \\ Covid- 9 pandemic phenomenon: approaches in Nussbaum and \\ Agamben
}

\section{"Crear capacidades" de sensibilidad y humanización en medio de la pandemia de Covid-19: reflexiones desde Nussbaum y Agamben}

Patricia Carlesso Marcelino I https://orcid.org/0000-0002-9084- I I 82

Altair Alberto Favero²

https://orcid.org/0000-0002-9187-7283

\begin{abstract}
Resumo: $O$ artigo tem como escopo refletir sobre a necessidade de "criar capacidades" para a sensibilidade e a humanização como antídoto para enfrentar a pandemia da Covid-19. Num cenário marcado por sentimentos de medo, desamparo, angústia, fragilidade, ignorância, cegueira moral e insensibilidade diante da morte, torna-se urgente e imprescindível criar espaços para experiências formativas que possibilitem solidariedade, acolhimento, empatia, vida compartilhada, sentimento de pertencimento, justiça social e cidadania. $O$ ensaio constitui-se num estudo qualitativo, caracterizado como bibliográfico e ancorado no método dedutivo-analítico, tendo como base as contribuições de Martha Nussbaum e Giorgio Agamben; propõe a ideia de "criar capacidades" como uma tarefa intransferível da educação para cultivar a sensibilidade humana diante de um cenário avassalador proporcionado pela pandemia.
\end{abstract}

Palavras-chave: Educação. Covid-19. Capacidades.

Abstract: The article aims to reflect on the need to "building capabilities" for sensitivity and humanization, as an antidote to tackle the Covid-19 pandemic. In a scenario marked by feelings of fear, helplessness, anguish, frailty,

\footnotetext{
'Doutora e Mestra em Educação pela Universidade de Passo Fundo (UPF-RS). Docente nas áreas de Educação, Estética e Cosmética, Saúde e Educação Física. É Terapeuta Floral e Personal Wellness com ênfase em Práticas Integrativas e Complementares em Saúde (PICS), Bem-Estar, Aromaterapia, Terapias Andinas e no atendimento especializado para pacientes oncológicos hospitalizados. Membro dos grupos de Pesquisa Teoria e Prática Pedagógica, NUPEFE e GEPES (UPF-RS). E-mail: patriciacarlessowellness@gmail.com

${ }^{2}$ Pós-Doutor pela Universidad Autónoma del Estado de México (UAEMéx), bolsista Capes, Doutor em Educação (UFRGS). Professor e pesquisador no Curso de Filosofia, Coordenador do Programa de Pós-Graduação em Educação - Mestrado e Doutorado da Universidade de Passo Fundo (UPF-RS). Líder do Grupo de Estudos e Pesquisas em Educação Superior (GEPES/UPF). E-mail: altairfavero@gmail.com
}

Olhar de professor, Ponta Grossa, v. 24, p. I-19, e-15980.01 I, 202I.

Disponível em <https://revistas2.uepg.br/index.php/olhardeprofessor> 
ignorance, moral blindness and insensitivity in the face of death, it becomes urgent and indispensable to create spaces for formative experiences that enable solidarity, acceptance, empathy, shared life, sense of belonging, social justice, and citizenship. The essay is a qualitative study, characterized as bibliographic and was anchored in the deductive-analytical method, based on the contributions of Martha Nussbaum and Giorgio Agamben; It proposes the idea of "building capacities" as an untransferable task of education to cultivate human sensitivity in the face of an overwhelming scenario provided by the pandemic.

Key-words: Education. Covid-19.Capabilities.

Resumen: El artículo pretende reflexionar sobre la necesidad de "crear capacidades" de sensibilidad y humanización como antídoto para enfrentar la pandemia Covid-19. En un escenario marcado por sentimientos de miedo, desamparo, angustia, fragilidad, ignorancia, ceguera moral e insensibilidad ante la muerte, es urgente e imprescindible crear espacios de vivencias formativas que posibiliten la solidaridad, la aceptación, la empatía, la vida compartida, el sentimiento de pertenencia, justicia social y ciudadanía. El ensayo es un estudio cualitativo, caracterizado por ser bibliográfico y anclado en el método deductivo-analítico, basado en los aportes de Martha Nussbaum y Giorgio Agamben; propone la idea de "crear capacidades" como una tarea educativa intransferible para cultivar la sensibilidad humana ante un escenario abrumador que brinda la pandemia.

Palabras clave: Educación. Covid-19. Capacidades.

\section{Introdução}

Talvez um dos sentimentos mais compartilhados e evidentes do atual cenário é o da crise de nosso tempo. De todos os lados, escutamos, percebemos, respiramos, somos absorvidos por sua presença: crise de governo, crise institucional, crise econômica, crise do desemprego, crise humanitária, crise existencial, crise da razão, crise da ciência, crise sanitária...e a lista poderia ser imensa ou até infinita. No entanto, no início de 2020, o planeta inteiro foi sacudido por uma gigantesca avalanche chamada COVID-19, que está alterando ou certamente alterará a vida de todos nós, das instituições que fazemos parte e da forma como se dão as relações humanas nesse contexto. Possivelmente, estamos vivendo uma das maiores crises do século $\mathrm{XXI}$.

A palavra crise ou o que ela designa, geralmente, é traduzida por algo negativo, ou algo que não vai bem. Quando uma determinada sociedade vive um alto índice de desemprego, queda no consumo, perda expressiva de renda da maioria das pessoas, economia em baixa, precarização das condições de trabalho e recessão, frequentemente, diz que está passando por uma crise econômica. Quando alguém se sente vazio, sem perspectiva de vida, sem projetos e sonhos, geralmente, diz que este alguém vive uma crise existencial. Quando um determinado governo tem dificuldade para articular um conjunto de políticas (econômicas, sociais, comerciais, internacionais), tem dificuldade de se relacionar com outros poderes, causa escândalos, está em permanente guerra com a imprensa ou com outros partidos políticos, está ameaçado de sofrer um processo de impeachment, atribui-se a essa situação a ideia de crise política. E os exemplos poderiam ser extensivos a todas as outras crises.

No entanto, a palavra crise também pode significar oportunidade. É que nos diz com propriedade Duarte Júnior (2006, P. 69), quando lembra que, na cultura chinesa, “o conceito de crise é wei-ji, locução composta pela junção dos ideogramas perigo e oportunidade”. Compreendida dessa 
maneira, crise não é somente uma situação arriscada, delicada, ameaçadora, perigosa, causadora de medo, insegurança, vulnerabilidade, morte; a crise pode ser também uma oportunidade para repensarmos nosso rumo societário, nossas relações, nossos projetos de vida, nossa própria existência, nosso estar no mundo. A crise, torna-se, dessa perspectiva, um sinal de alerta para revermos os rumos, as escolhas, os valores, as prioridades, o que realmente importa.

O presente artigo tem como objetivo refletir sobre a necessidade de "criar capacidades" para a sensibilidade e a humanização como antídoto para enfrentar a pandemia do Covid-19. Num cenário marcado por sentimentos de medo, desamparo, angústia, fragilidade, ignorância, cegueira moral e insensibilidade diante da morte, torna-se urgente e imprescindível criar espaços para experiências formativas que possibilitem solidariedade, acolhimento, empatia, vida compartilhada, sentimento de pertencimento, justiça social, e cidadania.

O ensaio constitui-se num estudo qualitativo, caracterizado como bibliográfico e ancorado no método dedutivo-analítico, tendo como base as contribuições de Martha Nussbaum e Giorgio Agamben; Propõe a ideia de "criar capacidades" como uma tarefa intransferível da educação para cultivar a sensibilidade humana diante de um cenário avassalador proporcionado pela pandemia.

\section{A Covid-19 na perspectiva de alguns pensadores contemporâneos}

Dardot e Laval (2020) apontam que a pandemia da Covid-19 é expressão de uma crise global, sanitária, econômica e social excepcional. Poucos acontecimentos históricos podem ser comparados a ela, pelo menos na escala das últimas décadas. Não deixa de ser uma certa tragédia que agora se afigura como um teste para toda a humanidade. Trata-se de uma provação no duplo sentido das palavras: dor, risco e perigo, por um lado; teste, avaliação e julgamento, por outro. O que a pandemia está testando é a capacidade das organizações políticas e econômicas de lidar com um problema global vinculado à interdependência dos indivíduos, ou seja, algo que afeta de uma forma básica a vida social de todos. Como uma distopia que se torna realidade, o que estamos experimentando revela aquilo que, com as mudanças climáticas em curso, aguarda a humanidade em poucas décadas se a estrutura econômica e política do mundo não mudar muito rápida e radicalmente.

Santos (2020), por sua vez, ressalta que os debates culturais, políticos e ideológicos do nosso tempo têm uma opacidade estranha que decorre da sua distância em relação ao quotidiano vivido pela grande maioria da população, os cidadãos comuns - «la gente de a pie», como dizem os latinoamericanos:

Em particular, a política, que devia ser a mediadora entre as ideologias e as necessidades e aspirações dos cidadãos, tem vindo a demitir-se dessa função. Se mantém algum resíduo de mediação, é com as necessidades e aspirações dos

Olhar de professor, Ponta Grossa, v. 24, p. I-19, e-I5980.01 I, 202 I.

Disponível em <https://revistas2.uepg.br/index.php/olhardeprofessor> 
“Criar capacidades" para a sensibilidade e a humanização em meio à pandemia de Covid-19...

mercados, esse megacidadão informe e monstruoso que nunca ninguém viu nem tocou ou cheirou, um cidadão estranho que só tem direitos e nenhum dever. É como se a luz que ele projeta nos cegasse. De repente, a pandemia irrompe, a luz dos mercados empalidece, e da escuridão com que eles sempre nos ameaçam se não the prestarmos vassalagem emerge uma nova claridade (SANTOS, 2020, p. 10).

O autor reforça que a claridade pandêmica e as aparições em que ela se materializa permitemnos ver e avaliar o futuro da civilização em que vivemos. Essas aparições, ao contrário de outras, são reais e vieram para ficar, mas ele finaliza de maneira pouco animadora, quando afirma que:

As pandemias mostram de maneira cruel como o capitalismo neoliberal incapacitou o Estado para responder às emergências. As respostas que os Estados estão a dar à crise variam de Estado para Estado, mas nenhum pode disfarçar a sua incapacidade, a sua falta de previsibilidade em relação a emergências que têm vindo a ser anunciadas como de ocorrência próxima e muito provável. Estou certo de que nos próximos tempos esta pandemia nos dará mais lições e de que o fará sempre de forma cruel. Se seremos capazes de aprender é por agora uma questão em aberto (SANTOS, 2020, p. 32).

Em suas reflexões, Davis (2020a) salienta que o acesso a medicamentos, incluindo vacinas, antibióticos e antivirais, deveria ser um direito humano, universalmente disponível e sem custos. Se os mercados não podem oferecer incentivos para produzir tais medicamentos a baixo custo, então, governos e organizações sem fins lucrativos deveriam assumir a responsabilidade por sua fabricação e distribuição, pois a sobrevivência dos pobres deve ser sempre considerada uma prioridade maior do que os lucros da indústria farmacêutica.

A atual pandemia expande esse argumento: a globalização capitalista parece agora biologicamente insustentável na ausência de uma verdadeira infraestrutura de saúde pública internacional. Mas tal infraestrutura nunca existirá enquanto os movimentos populares não quebrarem o poder da indústria farmacêutica e dos cuidados de saúde com fins lucrativos.

Nessa direção de argumentação, Davis (2020a) reforça que o capital modifica as condições ambientais de sua própria reprodução, mas o faz num contexto de consequências não intencionais (como as mudanças climáticas) e contra as forças evolutivas autônomas e independentes que estão perpetuamente remodelando as condições ambientais. Desse ponto de vista, não existe um verdadeiro desastre natural. Os vírus mudam o tempo todo. Mas as circunstâncias nas quais uma mutação tornase uma ameaça à vida dependem das ações humanas.

Há dois aspectos relevantes nisso, conforme explica Davis (2020b), primeiro, as condições ambientais favoráveis aumentam a probabilidade de mutações fortes. É plausível, por exemplo, esperar que sistemas de fornecimento alimentar intensivos ou abusivos em subtrópicos úmidos possam contribuir para isso. Tais sistemas existem em muitos lugares, incluindo a China ao Sul do Yangtse e do Sudeste Asiático. Em segundo lugar, as condições que favorecem a transmissão rápida através dos 
corpos hospedeiros variam muito. Populações humanas de alta densidade pareceriam alvos fáceis do hospedeiro. É bem conhecido que as epidemias de sarampo, por exemplo, só se manifestam em grandes centros populacionais urbanos, mas desaparecem rapidamente em regiões pouco povoadas.

A forma como os seres humanos interagem uns com os outros, movem-se, disciplinam-se ou esquecem-se de lavar as mãos, afeta, segundo Davis (2020b), a forma como as doenças são transmitidas. Em tempos recentes, a SARS, as gripes aviária e suína parecem ter saído da China ou do sudeste asiático. A China também sofreu muito com a gripe suína em 2019, o que implicou o abate em massa de suínos e a escalada dos preços da carne de porco.

O próprio Davis (2020b) ressalta que não se trata de fazer acusações oportunistas, no sentido de ficar indicando esse ou aquele país como sendo responsável pela disseminação de uma determinada pandemia. De fato, há muitos possíveis lugares onde os riscos ambientais de mutação e difusão de vírus são elevados. A gripe espanhola de 1918, por exemplo, pode ter saído do Kansas e a África pode ter incubado o HIVIAIDS, certamente iniciado, no Nilo Ocidental, o Ebola, enquanto a dengue parece que floresceu na América Latina.

Com essas reflexões, Davis (2020b) argumenta que o impacto econômico e demográfico da disseminação do vírus depende de fissuras e vulnerabilidades preexistentes no modelo econômico hegemônico. Com isso, destaca que não deveria causar surpresa o fato de que o COVID-I 9 tenha sido encontrado, inicialmente, em Wuhan (embora não se saiba se, de fato, teve sua origem lá). Os efeitos locais seriam substanciais e dado que este era um centro de produção importante, provavelmente, haveria repercussões econômicas globais (embora não tivesse ideia da magnitude).

A grande questão levantada por Davis (2020a) consiste em compreender como se dá o contágio, como a difusão pode ocorrer e quanto tempo durará (até que uma vacina pudesse ser encontrada). Experiências anteriores já mostraram que uma das desvantagens da crescente globalização consiste no fato de ser impossível deter uma rápida difusão internacional de novas doenças. Vivemos em um mundo altamente conectado, em que quase todos viajam. As redes humanas de difusão potencial são vastas e abertas e, por isso, o perigo (econômico e demográfico) que uma pandemia pode proporcionar em termos globais.

Davis (2020a) também denuncia que a indústria farmacêutica tem pouco ou nenhum interesse na pesquisa sem fins lucrativos sobre doenças infecciosas (como toda a classe de coronavírus conhecida desde os anos 60). De fato, a indústria farmacêutica raramente investe em prevenção, pois tem pouco interesse em investir na preparação para uma crise de saúde pública. "Desenhar curas” é mais lucrativo do que investir na prevenção. Quanto mais doentes nós estamos, mais a indústria farmacêutica lucra. A prevenção não contribui para uma valorização dos acionistas. $O$ modelo de negócio aplicado à oferta de saúde pública eliminou a capacidade de resposta que seria necessária em caso de emergência. $\mathrm{A}$

Olhar de professor, Ponta Grossa, v. 24, p. I-19, e-15980.01I, 2021.

Disponível em <https://revistas2.uepg.br/index.php/olhardeprofessor> 
“Criar capacidades” para a sensibilidade e a humanização em meio à pandemia de Covid-19...

prevenção nem sequer era um ramo de trabalho sedutor o suficiente para justificar parcerias públicoprivadas.

O descaso com doenças que ameaçam as populações mais pobres é negligenciado pelos governos que se alinham a um projeto ultra liberal. É o que exemplifica Davis (2020a), quando se refere aos cortes ao orçamento do Centro de Controle de Doenças e a dissolução do grupo de trabalho sobre pandemias no Conselho Nacional de Segurança, o que foi feito pelo presidente Trump. "Se eu quisesse ser antropomórfico e metafórico sobre isso", afirma Davis (2020a, p. 4), "concluiria que a COVID-19 é a vingança da natureza por mais de quarenta anos de maus-tratos grosseiros e abusivos da natureza sob a tutela de um extrativismo neoliberal violente e desregulado".

$\mathrm{Na}$ tentativa de situar o atual cenário de crise, Agamben (2020) explica que há dois fatores que podem ajudar a compreender o fenômeno do comportamento desproporcionado gerado pela pandemia:

a) Em primeiro lugar, há uma tendência crescente a utilizar o estado de exceção como paradigma normal de governo, impondo as graves restrições por meio de decretos por "razões de saúde e seguridade pública";

b) O segundo fator é a instauração de um "estado de medo" na consciência dos indivíduos provocando um estado de pânico coletivo. Assim, o pretexto da pandemia acaba instituindo uma espécie de militarização da sociedade e a imposição de graves restrições à liberdade e a vigilância ativa.

Cria-se, assim, um círculo vicioso perverso, em que a limitação da liberdade imposta pelos governos é aceita, em nome de um desejo de segurança, que tem sido induzido pelos mesmos governos que agora intervêm para satisfazê-la.

O que percebemos nesse cenário de barbárie é a valorização exagerada da economia, em detrimento da valorização da vida humana. Trata-se de desvelar os processos (de)formativos da sacralização ou da adaptabilidade da vida, que Agamben (2020), denomina de Homo Sacer, ou seja, o homem disponibilizado para o sistema. Em sua interpretação, vivemos tempos em que, apesar de todos os discursos tenderem para a inclusão, a exceção literalmente virou a regra, ou melhor, normalizouse a exceção na biopolítica moderna, ficando a vida nua incluída pelo poder político através da exclusão, pondo, assim, em xeque a noção de cidadania oferecida pelo estado democrático de direito. Com isso, "a degeneração das relações entre os homens", o distanciamento, ○ fechamento das instituições formativas, a virtualidade das relações, o medo do contágio. É como se a pandemia criasse o ambiente favorável para a substituição de todo e qualquer contato humano pela mediação das máquinas.

Santos (2020, p.31-32), por sua vez, explica que é necessário que se faça uma nova articulação, uma espécie de viragem epistemológica, cultural e ideológica capaz de sustentar as soluções políticas, econômicas e sociais que garantam a continuidade da vida humana digna no planeta. Essa viragem tem

Olhar de professor, Ponta Grossa, v. 24, p. I-19, e-I5980.01 I, 2021.

Disponível em <https://revistas2.uepg.br/index.php/olhardeprofessor> 
múltiplas implicações: a primeira consiste em criar um novo senso comum, a ideia simples e evidente de que, sobretudo, nos últimos quarenta anos, vivemos em quarentena política, cultural e ideológica de um capitalismo fechado sobre si próprio e das discriminações raciais e sexuais, sem as quais ele não pode subsistir. A quarentena provocada pela pandemia é afinal uma quarentena dentro de outra quarentena. Superaremos a quarentena do capitalismo quando formos capazes de imaginar o planeta como a nossa casa comum e a Natureza como a nossa mãe originária a quem devemos amor e respeito. Ela não nos pertence. Nós é que the pertencemos. Quando superarmos essa quarentena, estaremos mais livres das quarentenas provocadas por pandemias. Para tanto, ele registra: "só com uma nova articulação entre os processos políticos e os processos civilizatórios será possível começar a pensar numa sociedade em que humanidade assuma uma posição mais humilde no planeta que habita". Para que isso aconteça, a humanidade necessita compreender que "há muito mais vida no planeta do que a vida humana, já que esta representa apenas $0,01 \%$ da vida existente”; além disso é necessário conscientizarmo-nos e comprometermo-nos com "a defesa da vida do planeta no seu conjunto" como sendo uma condição fundamental para a continuação da vida da humanidade. Se a humanidade continuar a pôr em causa e a destruir todas as outras vidas, de que é feito o planeta Terra, então "é de se esperar que essas outras vidas se defendam da agressão causada pela vida humana e o façam por formas cada vez mais letais". Nesse caso, reforça-se o pensador português, "o futuro desta quarentena será um curto intervalo antes das quarentenas futuras".

Zizek (2020) dá-nos uma possível esperança a partir da experiência da pandemia quando indica a possibilidade de existir outro vírus ideológico, muito mais benigno, o qual também deva alastrar-se, com sorte, infectar a todos nós. Trata-se do vírus de começarmos a pensar em possibilidades alternativas de sociedade, possibilidades para além do Estado-nação, e, desse modo, atualizar as formas de cooperação e solidariedade globais. Muito se especula hoje que o coronavírus pode levar à queda do governo comunista na China, da mesma forma que (como o próprio Gorbatchov admitiu) a catástrofe de Chernobyl foi o acontecimento que deflagrou o fim do comunismo soviético. Mas há um paradoxo aqui: pois o coronavírus também deve nos estimular a reinventar o comunismo com base na confiança no povo e na ciência.

Dardot e Laval (2020) ainda reforçam que como os principais riscos são globais, a ajuda mútua deve ser global, as políticas devem ser coordenadas, os meios e o conhecimento devem ser compartilhados, a cooperação deve ser a regra absoluta. Saúde, clima, economia, educação, cultura não devem mais ser considerados propriedade privada ou propriedade estatal: devem ser considerados bens comuns globais e instituídos politicamente como tais. Uma coisa é certa agora: a salvação não virá de cima. Somente insurreições, levantes e coalizões transnacionais de cidadãos podem impor isso aos Estados e ao capital. 
“Criar capacidades" para a sensibilidade e a humanização em meio à pandemia de Covid-19...

A breve síntese reconstrutiva dos posicionamentos e reflexões apresentadas por todos esses pensadores teve como intenção situar nossa reflexão sobre a atual crise provocada pela pandemia do COVID-19. No próximo tópico, nossa reflexão se concentrará nos escritos da filósofa norte americana Martha Nussbaum, especificamente sobre sua teria das capacidades. Nesse contexto fragilizado de desumanização e humanização, de valorização e de desvalorização da vida humana, nossa hipótese de trabalho é que os processos formativos precisam "criar capacidades" para que saibamos ser mais humanos, mais sensíveis, mais solidários e mais virtuosos, mais autênticos e menos egoístas, menos consumistas e menos centrados nos valores exclusivamente materiais.

\section{“Criar capacidades" em um tempo de barbárie e de exclusão}

As democracias possuem uma grande capacidade racional e criadora, mas também estão sujeitas a alguns erros de análise, ao provincianismo, à precipitação, à omissão, ao egoísmo e à estreiteza de espírito. Segundo Nussbaum (2015), a educação baseada principalmente na lucratividade do mercado global amplia essas deficiências, criando uma estupidez gananciosa, que põe em risco a própria existência de uma cultura mundial satisfatória.

Para Nussbaum (20I5), se o verdadeiro choque de civilizações dá-se quando ocorre um choque no interior dos indivíduos, à medida que a ganância e o narcisismo lutam contra o respeito e o amor, então todas as sociedades modernas perdem rapidamente a batalha, já que elas alimentam as forças que conduzem à violência e à desumanização e deixam de alimentar as forças que conduzem cultura de igualdade e respeito.

O modelo de desenvolvimento humano, segundo Nussbaum (20I5), está comprometido com a democracia, uma vez que pode opinar na escolha das políticas que governam sua própria vida, é um ingrediente essencial de uma vida merecedora de dignidade humana. No entanto, o tipo de democracia que ele favorece será o que atribui um papel importante a direitos fundamentais que não possam ser retirados das pessoas por meio de caprichos da maioria - assim, ele favorecerá uma firme proteção da liberdade política; a liberdade de palavra, de associação e de prática religiosa; e direitos fundamentais em outras áreas da educação e saúde.

Nussbaum (2015, p. 26) sinaliza também que se um país quiser favorecer esse tipo de democracia humana e sensível ao povo, dedicada a promover oportunidades de "vida, liberdade e busca de felicidade" a todos, com algumas competências, pode ser possível gerar a difusão a partir da formação e educação das seguintes capacidades:

a) Capacidade de raciocinar adequadamente a respeito de temas políticos que afetem a nação, de examinar, de refletir, argumentar e debater não se submetendo nem à tradição nem à autoridade; Capacidade de reconhecer seus concidadãos como pessoas com direitos iguais, mesmo que sejam

Olhar de professor, Ponta Grossa, v. 24, p. I-19, e-I5980.01 I, 2021.

Disponível em <https://revistas2.uepg.br/index.php/olhardeprofessor> 
diferentes quanto à raça, religião, gênero e orientação sexual: olhá-los com respeito, como fins, não como ferramentas a serem manipuladas em proveito próprio;

b) Capacidade de se preocupar com a vida dos outros. De compreender o que as diferentes políticas significam para as oportunidades e experiências dos diferentes tipos de concidadãos e para as pessoas que não pertencem a seu próprio país; Capacidade de conceber cabalmente diversos assuntos complexos que afetam a história da vida humana em seu desenvolvimento: refletir acerca da infância, da adolescência, das relações familiares, da doença, da morte e muito mais, de forma que se caracterize pela compreensão de um amplo conjunto de histórias humanas, não apenas pela reunião de informações;

c) Capacidade de julgar criticamente os líderes políticos, mas com uma compreensão fundamentada e realista das possibilidades de que eles se dispõem e também na capacidade de pensar no bem da nação como um todo, não somente no bem do seu próprio local;

d) Capacidade de perceber o seu próprio país como parte de um mundo complexo, em que diferentes tipos de assuntos exigem uma discussão transacional inteligente para que sejam solucionados.

Além dessas capacidades, Nussbaum (2015, p.I43) reitera a importância da educação:

Educação é para gente. Antes de podermos planejar um sistema educacional, precisamos entender os problemas que enfrentamos para transformar alunos em cidadãos responsáveis que possam raciocinar e fazer uma escolha adequada a respeito de um grande conjunto de temas de importância nacional e internacional (NUSSBAUM, 20I5, p. 143).

Sendo assim, Kohls (2019) enfatiza que todo o contexto contribui para uma formação que vise produzir um sujeito competitivo, capaz de se adaptar ao mercado, ao invés de questioná-lo e reinventálo. Disso resulta uma cultura acadêmica desvinculada das humanidades, da formação integral, do ser humano, muito antes ao contrário, essa supremacia do econômico sobre o humano tem muito mais promovido um adestramento por meio de uma "gestão das mentes" do que promovido a libertação dos indivíduos.

No horizonte da educação, inicia-se um processo de desativação dos enormes gastos de energia em debates estéreis, como sinaliza Strieder (2004), mesmo diante de um panorama difícil e, por vezes, desestimulador, pode-se aclamar com certo teor otimista o surgimento de consciências, querendo refletir inúmeras urgências educacionais. A educação começa a sentir a presença indissociável de seu papel/compromisso para com a vida de seres humanos concretos e reais. Devagar, com uma âncora "mais ou menos" segura, buscam-se os vínculos com ênfase num novo binômio: educar/vida. A profusão de divergências presentes na diversidade da vida começa a fazer jus a inúmeros destaques.

Olhar de professor, Ponta Grossa, v. 24, p. I-19, e-15980.01I, 202I.

Disponível em <https://revistas2.uepg.br/index.php/olhardeprofessor> 
“Criar capacidades" para a sensibilidade e a humanização em meio à pandemia de Covid-19...

A vida, segundo o autor, já não se enquadra mais nos esquematismos formalizados por paradigmas mecanicistas e simplificadores. A vida e o viver manifestam-se em múltiplas referências. $O$ ingrediente da multi-refencialidade recorre à versatilidade dinâmica, reprimida violentamente na concepção fragmentária e mecanicista da vida:

As linguagens pedagógicas que apostam na reconstrução da esperança de incluir na dinâmica da vida, a não resignação, é também uma aposta no desenvolvimento da sensibilidade solidária. É nesse sentido que o tema da sensibilidade e da solidariedade emerge como desafio de uma educação para a humanização. Uma educação que, juntamente como o pressuposto de "salvar vidas", requer-se o imperativo de contribuir para "salvar a humanidade", respeitando a diversidade (STRIEDER, 2004, p. 21).

Duarte Júnior (2006) também reforça a necessidade de se discutir sobre o quanto uma educação voltada para o sensível pode, pela recuperação de velhas técnicas populares, contribuir para um melhor aproveitamento daquilo que se tem em volta, com a consequente diminuição desse desmedido desperdício tão corriqueiro em nossa sociedade contemporânea. Saber perceber o mundo ao redor, em termos dos materiais e substâncias que o compõem, coletando-as e trabalhando-as artesanalmente consiste, com efeito, numa maneira de estabelecer vínculos mais sensíveis com a natureza. Assim, a ecologia, a sensibilidade e a educação revelam o quão interligados podem estar se não forem tomadas como partes independentes de um conhecimento fragmentário e desvinculado da vida de cada um.

A sensibilidade, a humanização e o cuidado de si e do outro, segundo Marcelino (2019), são ferramentas poderosíssimas para quem escolher o posicionamento de fazer a diferença em seu entorno. É uma capacidade que pode ser aprendida em todos os contextos, através de atos e de exemplos, de gentileza e delicadeza, nesses tempos de barbárie, de egoísmo, de egocentrismo, de desrespeito e de exclusão.

É importante que possamos ter a capacidade de valorizar mais as pessoas e não as coisas, e que possamos exercitar mais a cooperação do que a competição. A partir dessa escolha e de uma mudança interna, nossos comportamentos determinarão nosso posicionamento frente aos acontecimentos, à natureza e, principalmente, frente às pessoas e a tudo que nos cerca.

\section{O caminho para a sensibilidade e a humanização}

A ideia de pavimentar um caminho mobilizado pela sensibilidade e humanização tem como intenção promover atitudes e comportamentos, no sentido de fazer da educação uma via privilegiada de reconstrução da cidadania e da democracia num contexto de lutas e debates em torno do reconhecimento cultural e da redistribuição da riqueza. De acordo com Barbosa (2006), perspectiva-

Olhar de professor, Ponta Grossa, v. 24, p. I-19, e-15980.01 I, 202 I.

Disponível em <https://revistas2.uepg.br/index.php/olhardeprofessor> 
se, com isso, promover um ambiente de crescente diferenciação cultural das sociedades e, com isso, implementar a inscrição da sensibilização e humanização em esferas globais ou mundiais, possibilitando a abertura para as cidadanias emergentes, necessariamente mais plurais, interculturais e também cosmopolitas.

Agamben (2019) afirma quevivemos tempos em que, apesar de todos os discursos tenderem para a inclusão, a exceção literalmente virou a regra, ou melhor, normalizou-se a exceção na biopolítica moderna, ficando a vida nua incluída pelo poder político através da exclusão, pondo, dessa forma em xeque a noção de cidadania oferecida pelo estado democrático de direito. No entanto, toda a tentativa de inclusão continua revelando sua limitação, circunstância, mantém-se o potencial da vida sempre desenvolver novas formas de ser no mundo. A vida é um ato de criação e descriação constante, e, nisso, o corpo apresenta-se como fonte de resistência contra sua completa dominação.

Agamben (2019) defende a indeterminação e a abertura na aventura pela vida: da aventura, porém, interessa-nos aqui um outro aspecto. Na medida em que exprime unidade indiscernível entre o evento e narrativa, coisa e palavra, ela pode não ter, para além do seu valor poetológico, um significado propriamente ontológico. Se é verdadeiro que a figura que o nosso tempo propõe-nos é aquela de uma vida insacrificável, que, todavia, tornou-se matável em uma proporção inaudita, então, a "vida nua" do Homo Sacer diz-nos respeito de modo particular. A sacralidade é uma linha de fuga ainda presente na política contemporânea, que, como tal, desloca-se em direção a zonas cada vez mais vastas e obscuras, até coincidir com a própria vida biológica dos cidadãos.

Todos os seres vivos, para Agamben (2017), estão em uma forma de vida, mas nem todos são (ou nem sempre são) uma forma de vida. No momento em que a forma de vida constitui-se, ela constitui e torna inoperosas todas as formas de vida singulares. Só vivendo uma vida é que se constitui uma forma de vida, como a inoperosidade, que é imanente em cada vida. A constituição de uma forma de vida coincide, portanto, integralmente, com a destituição das condições sociais e biológicas em que ela se acha lançada. A forma de vida é, neste sentido, a revogação de todas as vocações factícias, que ela depõe e tenciona a partir de dentro, no gesto mesmo em que se mantém e habita nelas.

Zizek (2020) também nos adverte que, por esse motivo, é de se esperar que as epidemias virais terão impacto nas nossas interações mais elementares com outras pessoas, com os objetos à nossa volta e, inclusive, com nossos próprios corpos. Evite entrar em contato com coisas que poderiam estar “contaminadas", não toque em livros, não sente em privadas públicas ou em bancos públicos, procure não abraçar os outros e apertar suas mãos... talvez até fiquemos mais ciosos sobre nossos gestos espontâneos: não mexa muito no nariz, evite esfregar os olhos e coçar o corpo, ou seja, não é apenas o Estado e outras instâncias que nos controlarão: devemos aprender a controlar e disciplinar a nós mesmos. 
“Criar capacidades" para a sensibilidade e a humanização em meio à pandemia de Covid-19...

Talvez, segundo Zizek (2020), apenas a realidade virtual seja considerada segura e deslocar-se livremente em um espaço aberto torne-se algo reservado para as ilhas privativas dos ultra-ricos. Mas mesmo no nível da realidade virtual e da internet, vale lembrar que, nas últimas décadas, os termos "vírus" e "viral" eram usados principalmente para designar fenômenos digitais que estavam infectando nosso espaço-virtual e dos quais não estávamos cientes, ao menos não até que seu poder destrutivo (digamos, de corromper nossos dados ou torrar nossos HDs) fosse liberado. O que estamos testemunhando agora é um retorno massivo ao significado literal originário do termo. As infecções virais operam de mãos dadas em ambas as dimensões, real e virtual.

Agamben (2020), no entanto, destaca um novo cenário para educação superior europeia, a partir da pandemia, e pressagia com muita negatividade suas consequências para esse contexto, em seu último artigo, publicado na Itália, intitulado: "Réquiem para os estudantes" e que, segundo o autor, como havíamos previsto, as aulas universitárias realizar-se-ão online no próximo ano. Aquilo que, para um observador atento, era evidente, isto é, que a pretensa pandemia seria utilizada como pretexto para a disseminação alastrante da tecnologia digital, realizou-se pontualmente. Não nos interessa aqui a consequente transformação da didática, cujo elemento da presença física, sempre tão importante na relação entre estudantes e docentes, desaparece definitivamente, como desaparecem as discussões coletivas nos seminários, que eram a parte mais viva do ensino. Faz parte da barbárie tecnológica que estamos vivendo o cancelamento da vida de cada experiência dos sentidos e a perda do olhar, duradouramente aprisionado em um ecrã espectral.

Agamben (2020) afirma que, bem mais decisivo no que se está sucedendo, é algo de que significativamente não se fala em absoluto, a saber, o fim do estudantado como forma de vida. As universidades nasceram na Europa a partir de associações de estudantes - universitates -, e devem a estas o seu nome. Aquela do estudante, a saber, era antes de tudo uma forma de vida em que, certamente, era determinante o estudo e a escuta das lições, mas não menos importantes eram o encontro e a contínua troca com os demais scholarii, que frequentemente vinham dos lugares mais remotos e reuniam-se em nationes de acordo com o lugar de origem. Essa forma de vida evoluiu de diversos modos ao longo dos séculos, mas era constante, desde os clerici vagantes do medievo aos movimentos estudantis do século XX, a dimensão social do fenômeno. Quem quer que tenha ensinado em uma aula universitária sabe bem como, por assim dizer, sob seus olhos formavam-se as amizades e constituíam-se, conforme os interesses culturais e políticos, pequenos grupos de estudo e de pesquisa, que continuavam a encontrar-se mesmo depois do fim da aula.

Tudo isso, que durara por quase dois séculos, agora termina para sempre. Agamben (2020) sinaliza que os estudantes não viverão mais na cidade em que está sediada a universidade, antes cada um escutará as lições fechado em seu aposento, separado às vezes por centenas de quilômetros 
daqueles que foram antes seus colegas. As pequenas cidades, outrora sedes de universidades de prestígio, verão desaparecer de suas ruas aquela comunidade de estudantes que frequentemente lhe constituíam a parte mais viva.

De todo fenômeno social que morre, pode-se afirmar que, em um certo sentido, merecia o seu fim e é certo que nossas universidades chegaram a tal ponto de corrupção e de ignorância especialística que não é possível lamentar-the e que a forma de vida dos estudantes era, em consequência igualmente, empobrecida. Dois pontos, segundo Agambem (2020), devem, no entanto, restar firmes: 1) Os professores que aceitam - como estão fazendo em massa -, submeter-se à nova ditadura telemática e realizar os seus cursos somente online são ○ perfeito equivalente dos docentes universitários (italianos), que, em 1931, juraram fidelidade ao regime fascista. Como aconteceu, então, é provável que apenas quinze de cada mil se recusarão, mas, certamente, seus nomes serão lembrados ao lado daqueles quinze docentes que não juraram. 2) Os estudantes que verdadeiramente amam o estudo deverão recusar-se a inscrever-se em universidades transformadas desta maneira e, como em sua origem, constituir-se em novas universitates, somente no interior das quais, diante da barbárie tecnológica, poderá permanecer viva a palavra do passado e nascer - se nascerá -, algo como uma nova cultura.

Segundo o autor italiano, política e arte não são tarefas, nem simplesmente "obras": elas nomeiam, acima de tudo, a dimensão na qual as operações linguísticas e corpóreas, materiais e imateriais, biológicas e sociais são desativadas e contempladas como tais, a fim de libertar a inoperosidade que ficou aprisionada nelas. É nisso que reside o máximo bem que, segundo o filósofo, o homem pode esperar: "[...] uma alegria nascida disso, de que o homem contempla a si mesmo e a sua própria potência de agir" (AGAMBEN, 2017, p. 310).

Strieder e Girardi (2019), contudo, apontam-nos que a consciência torna-nos humanos criadores e geradores de possibilidades de um coexistir e um conviver na harmonia, sem negação de si próprio e do outro:

Nessa perspectiva, o convívio responsável inter-relacional volta-se às ações conscientes, como oportunidade de escolher existir no coexistir, viver no conviver e na autonomia reflexiva sem causar dano, de forma reiterada aos outros e ao entorno ambiente: "Ser terno com as pessoas, com o mundo e com os objetos pressupõe a desistência em apoderar-se do outro, de causar dor e sofrimento ao outro no contexto da antroposfera e/ou da biosfera". (STRIEDER; GIRARDI, 2019, p. 288).

Neste sentido, Strieder e Girardi (2019), explicam que os seres humanos encontram-se ainda em abismos de ignorância, em abismos de perdas, porque o apego violenta e registra-se em fracassos que expõem essa condição de pessoas desumanizadas, incapazes de conviver no amar e na biofilia.

Olhar de professor, Ponta Grossa, v. 24, p. I-19, e-15980.01I, 2021.

Disponível em <https://revistas2.uepg.br/index.php/olhardeprofessor> 
“Criar capacidades" para a sensibilidade e a humanização em meio à pandemia de Covid-19...

Insistimos em permanecer, praticamente, cegos em termos éticos e ambientais, por negarmos que o mal-estar na contemporaneidade e os danos causados à antroposfera e à biosfera são nossas criações. Mesmo vivendo numa configuração inconsciente de sentires relacionais, que negam a colaboração e o amar, somos seres humanos com possibilidades para construir reflexões e ações éticas conscientes e vivenciar a ternura como sendo nosso ser, vivenciar num conjunto social dedicado a colocar limites na agressividade, para que esta não se transforme em violência destruidora.

Para que isso possa ser alcançado, Marcelino (2019, p.187) reitera que nossas principais ferramentas são a capacidade de expressar a sensibilidade, a solidariedade e o amor. Com o desenvolvimento dessas capacidades, talvez seja possível iniciarmos nossas mudanças internas, tornando inoperosos, os dispositivos que nos normatizam, aprisionam, adoecem e desumanizam. É preciso reconhecer que nós conhecemos por influência de nossos sentimentos, pois o sentido não pode ser conhecido sem juízos de valor: o conhecimento do sentido é, antes de tudo, conhecimento que envolve o sentido e a afecção.

Só conhecemos efetivamente aquilo que nos afeta, aquilo com que nos envolvemos empaticamente e, agora, estamos todos no "mesmo mar" em meio a essa pandemia, mas não na mesma situação: milhares já morreram, outros milhões estão se afogando sem salva-vidas, bilhões nadando à deriva e alguns privilegiados salvos e seguros em seus barcos, também vimos na mídia a famosa "elite do atraso" contemplando tranquilamente o cenário que se apresenta, totalmente despreocupada, navegando em seus luxuosos iates ou passeando com seus jetskys...

Em meio a esse cenário desanimador, tem-se uma grande preocupação com os rumos da nossa educação, especialmente no que tange à educação institucionalizada, no quadro das políticas educativas estatais, o que, conforme Barbosa (2006), ganha cada vez mais importância na elaboração dessa resposta. A intenção, contando com o seu poder indutor de atitudes e comportamentos, é fazer da educação uma via privilegiada de reconstrução da cidadania e da democracia num contexto de lutas e debates em torno do reconhecimento cultural e da redistribuição da riqueza.

Nussbaum (2015) aponta como sugestão, para além desse currículo tradicional, a oferta de conteúdos que abordem questões culturais, religiosas, artísticas, de gênero, bem como oportunizam que os próprios alunos façam suas escolhas em cursos ou disciplinas que lhes interessa. Em outros exemplos, ela cita a mudança nas metodologias das aulas ou na organização dos cursos, em uma tentativa de oferecer uma formação mais ampla e diversificada. Perspectiva-se, assim, num ambiente de crescente diferenciação cultural das sociedades, bem assim da sua inscrição em esferas globais ou mundiais, a abertura para as cidadanias emergentes, necessariamente mais plurais, mais interculturais e também cosmopolitas. 
Nussbaum (2015) apresenta seu posicionamento e afirma que se não insistirmos na importância crucial das humanidades e das artes, elas vão desaparecer gradativamente porque não dão lucro. Elas só fazem o que é muito mais precioso do que isso: criam um mundo no qual vale a pena viver, pessoas que são capazes de enxergar os outros seres humanos como pessoas completas, com opiniões e sentimentos próprios que merecem respeito e compreensão, e nações que são capazes de superar o medo e a desconfiança em prol de um debate gratificante e sensato.

A autora sugere um currículo escolar e universitário que supere conteúdos tradicionais, que são, geralmente, trabalhos nas instituições educativas sem um objetivo maior de criticidade e imaginação. Uma educação ampla para a população, uma formação que não se restringe a competências úteis ao mundo empresarial. A educação na perspectiva de Nussbaum (2015) não consiste na assimilação passiva de dados e conteúdos culturais, mas em colocar desafios para que $o$ intelecto tornese ativo e competente, dotado de pensamento crítico para um mundo complexo.

\begin{abstract}
Esse pensamento é provocativo, pois sinaliza para a possibilidade de uma educação frustrada, que, ao invés de libertar, aprisiona, ao invés de emancipar, aliena, submetendo o homem a uma ordem que lhe é imposta com ares de modernidade. Caso queiramos contribuir para que as sociedades democráticas subsistam, é preciso colocar à mesa de debates as condições, os meios, os fins e os objetivos da formação, especialmente considerando as características de vida das novas gerações, compreendendo as reais necessidades que esse tempo histórico no qual estamos inseridos requer, para que os processos formativos tenham sentido e significado emancipador (KOHLS, 2019, p. 26).
\end{abstract}

Agamben (2019) adverte-nos que, as ciências humanas alcançarão, entretanto, seu decisivo limiar epistemológico somente quando repensarem, desde o início, a própria ideia de uma ancoragem ontológica, para olhar o ser como um campo de tensões essencialmente históricas. Ele defende a indeterminação e a abertura em nossa aventura pela vida. Almeja-se, neste sentido, que essa capacidade que Agamben, apresenta-nos de atrever-nos a aventurar possa ser realizada, especialmente por nós educadores, de maneira terna, sensível, respeitosa.

Marcelino (2019) assinala a importância dos aspectos supracitados e acrescenta que, na articulação entre a arte, a educação e com o corpo, podemos ter a oportunidade de propor e de usar ferramentas como a humanização, a sensibilidade, a empatia, a ética e a estética, que poderão servir como dispositivos libertadores dos mecanismos de imposição e de controle corporal, social, educacional e cultural. Acredita-se, segundo a autora, que uma vida mais sensível, provida de ternura por si e pelo outro, ofereça melhor qualidade ao viver, sendo imprescindível também enfatizar a importância de sempre seguir pelo viés de uma conduta ética e profissional em todos os contextos, somando-se a isso a necessidade de fazer do processo de formação a contemplação e atuação do viver saudável. 
“Criar capacidades" para a sensibilidade e a humanização em meio à pandemia de Covid-19...

É necessário muito mais que isso para que haja desenvolvimento humano. De acordo com Nussbaum, saber ler e escrever, por exemplo, dá acesso a algumas oportunidades de trabalho. No entanto, a educação não pode ficar restrita a isso, pois tem uma função social, que vai além da ideologia da profissionalização. Dessa maneira, poderá haver uma estreita ligação entre democracia e educação e, como consequência, em relação ao que denominamos uma formação para a cidadania. Sendo assim, parece-nos pertinente que se estabeleçam diálogos capazes de auxiliar na busca de alternativas e, quiçá, algumas respostas necessárias não só para evitar o definhamento da cidadania, como também para robustecer a democracia.

\section{Considerações finais}

Nesse contexto de pandemia, de exclusão e de visível desamparo social, especialmente no Brasil, realizamos a tentativa de tecer olhares e discutir os desafios da educação, no sentido de promover uma formação humana que preserve os princípios democráticos e de cidadania.

Nas reflexões anteriores, propomos uma educação e uma formação humana, direcionadas e constituídas por um viés mais amoroso e sensível, sendo uma opção nesse momento de dificuldades locais, regionais e mundiais extremamente desafiadoras que nos impôs essa situação. Concordarmos também que a educação é um dos elementos fundamentais na formação humana, e há que se considerar, nesse processo, a importância da docência.

A docência, a ação do professor, sua relação com o conhecimento e com os alunos têm sido temas permanentes de debates nos meios educacionais. Torna-se relevante, na perspectiva da busca de alternativas, que, em meio à multiplicidade de situações "novas" que envolvem o processo ensino e aprendizagem, possa encontrar-se parâmetros para validar a atuação docente, a relevância de conteúdos, especialmente frente ao avanço tecnológico e a crescente mercantilização da educação.

Contraditoriamente aos discursos que enaltecem os aparatos tecnológicos e as promessas de uma possível auto formação, o professor e a sua atuação são indispensáveis, enquanto ele atua como mediador e decodificador de significados, conceitos, sentidos e análise para a compreensão dos conhecimentos historicamente acumulados e isso, nesse momento, deve ser reforçado ao invés de enfraquecido. A partir da valorização e do fortalecimento da educação e da atuação docente, nossos comportamentos determinarão fortemente as consequências dos futuros acontecimentos e das lições que a pandemia nos deixará.

Tem razão Dowbor (2020, p.lI5), quando afirma que "o vírus Corona é de índole democrática", pois não tem preferências de classe, credo, etnia ou ideologia política. Mas infelizmente a sociedade não é democrática quando "os privilegiados têm sem dúvida mais meios de se proteger, com trabalho em casa pelo computador, em casa de campo, com amplos quartos que permitem evitar 
contatos diretos". Num país em que impera uma das mais gritantes e profundas desigualdades, com um sistema fragilizado de saúde, a grande massa dos despossuídos da população agrava a vulnerabilidade social. É nesta hora que nos damos conta de que é necessário aprender com a crise. Precisamos entender que, em tempos de pandemia, todos nós somos apenas seres humanos, vulneráveis, frágeis e que a tragédia direta ou indiretamente atinge a todos.

Solidariedade, compaixão, cooperação, olhar sensível, disponibilidade, generosidade deixam de ser apenas palavras e podem tornar-se decisivas nas atitudes que podem salvar vidas e promover a humanização, de modo que podemos canalizar nossas potencialidades para um bem comum. Pensar num mundo em que a humanidade use todas as potencialidades que ela desenvolveu até agora, não para a reprodução do capital que promove a concentração de riqueza ou para produzir mais consumismo e indivíduos dóceis e adestrados para a engrenagem biopolítica, mas para o aprimoramento de capacidades de humanização. Acreditar, lutar e promover ações que possibilitem esse tipo de humanidade pode soar, para muitos, ingenuidade e altruísmo exagerado.

Entretanto, como ressalta o jornalista Cardoso (2020, p.255), "trata-se de uma utopia realizável", que precisa ser repensada e reorganizada em tempos de crise como estamos vivendo. Espera-se, neste aspecto que a pandemia ajude-nos a entender que existem outras formas de organizar a vida social, que um outro mundo é possível e que as ideias não são abstrações inúteis e desnecessárias num mundo colonizado pela centralidade econômica e contaminada pela mentalidade consumista.

O reinvestimento da educação com esses sentidos e significados, sendo um sinal dos tempos que atravessamos, não deixa de criar desafios à docência, por mais legítimo e justificado que apareça aos decisores políticos. A aposta política na educação para a cidadania coloca necessariamente as práticas educativas perante a obrigação de se renovar, para que possa corresponder às exigências que doravante se colocam à formação de cidadãos e de sujeitos políticos. Serão as suas ideias renovadas e atualizadas, no quadro de uma teoria de ação educativa, que poderão induzir novos modos de fazer cidadanização para a democracia, especialmente nos contextos da educação básica e na educação superior.

Que a vida possa ser sentida, percebida e vivida de maneira consciente, e não simplesmente seja um objeto de uso para o trabalho e para o consumo, que essas experiências possam ser significativas e provedoras de sentidos, somando-se à necessidade de fazer da formação humana um processo de ativação de novos dispositivos capazes de promover novas formas de vida, tornando-a mais humanizada, amorosa e sensível. Trata-se de um longo caminho a seguir, e um imenso desafio que envolve coragem, amor pela educação, vontade, empatia, discernimento teórico, atitudes éticas e ações efetivas.

Olhar de professor, Ponta Grossa, v. 24, p. I-19, e-15980.01I, 2021.

Disponível em <https://revistas2.uepg.br/index.php/olhardeprofessor> 


\section{Referências}

AGAMBEN, G. Contagio. In: Sopa de Wuhan pensamiento contemporáneo em tiempos de pandemia. ASPO (Aislamiento Social Preventivo y Obligatorio. Pablo Amadeo Editor: La Plata, Buenos Aires, 2020.

AGAMBEN, G. Homo Sacer: o Poder Soberano e Vida Nua I. Belo Horizonte: UFMG, 2007.

AGAMBEN, G. La invención de uma epidemia. In: Sopa de Wuhan pensamiento contemporáneo em tiempos de pandemia. ASPO (Aislamiento Social Preventivo y Obligatorio. Pablo Amadeo Editor: La Plata, Buenos Aires, 2020.

AGAMBEN, G. O amigo e o que é um dispositivo? Chapecó: Argos, 2016.

AGAMBEN, G. O uso dos corpos - Homo Sacer IV, V. 2. Tradução: Selvino José Assmann. São Paulo: Boitempo, 2017.

AGAMBEN, G. Réquiem para os estudantes. Tradução: Davi de Conti, 2020. Disponível em: http://www.ihu.unisinos.br/599292-requiem-para-os-estudantes-artigo-degiorgioagamben?fbclid=IwAR3RADCVxDKBeo6LqyjoGJL0S7ji4 InsehJ6ZLtInNfm6egHAbcm4oAj4K4. Acesso em: 30 mai.2020.

AGAMBEN, G. Signatura Rerum sobre o Método. Tradução: Andrea Santurbano e Patrícia Peterle. São Paulo: Boitempo, 2019.

BARBOSA, M. Educação e Cidadania: renovação pedagógica. Amarante, Portugal: Labirinto, 2006.

BRASIL. Ministério da Saúde. Protocolo de manejo clínico para o novo coronavírus (2019-nCoV). Biblioteca Virtual em Saúde. 2020. Disponível em:http://www.saude.gov.br/bvs. Acesso em: 24 mar. 2020.

CARDOSO, W. Crise é oportunidade. In: TOSTES, A.; MELO FILHO, H. (org.). Quarentena: reflexões sobre a pandemia e depois. Bauru: Canal 6, 2020.

DARDOT, P.; LAVAL, C. A prova política da pandemia. In: Dossiê Boitempo COVID- I9. São Paulo: Boitempo, 2020. Disponível em: https://blogdaboitempo.com.br/dossies-tematicos/dossiecoronavirus/. Acesso em: 20 mai. 2020.

DAVIS, M. O coronavírus e a luta de classes: o monstro bate à nossa porta. In: Dossiê Boitempo COVID-19. São Paulo: Boitempo, 2020a. Disponível em: https://blogdaboitempo.com.br/dossiestematicos/dossie-coronavirus/. Acesso em: 20 mai. 2020.

DAVIS, M. Coronavírus e a luta de classes. Brasil: Terra sem Amos, $2020 \mathrm{~b}$.

DOWBOR, L. Além do coronavírus. In: TOSTES, A.; MELO FILHO, H. (org). Quarentena: reflexões sobre a pandemia e depois. Bauru: Canal 6, 2020.

DUARTE JÚNIOR, J. F. O sentido dos sentidos a educação (do) sensível. 4. ed. Curitiba: Criar Edições, 2006. 
MARCELINO, P. C. Humanização e Sensibilidade: Educação e Uso do Corpo em Giorgio Agamben. Tese (Doutorado em Educação) - Universidade de Passo Fundo, Passo Fundo, 2019, p.202.

NUSSBAUM, M. Crear Capacidades: propuestas para el desarrollo humano. Madrid: Paidós, 2012.

NUSSBAUM, M. Sem Fins Lucrativos: porque a Democracia precisa das Humanidades. Tradução: Fernando Santos. São Paulo: Martins Fontes, 2015.

KOHLS. R. C. Ensino Superior, crise das humanidades e a fragilidade democrática: reflexões a partir do pensamento de Martha Nussbaum. Tese (Doutorado em Educação) - Universidade de Passo Fundo, Passo Fundo, 2019, p. 210.

SANTOS, B. de S. A cruel Pedagogia do vírus. Almedina: Coimbra, 2020.

STRIEDER, R. Educar para a iniciativa e a solidariedade. 2. ed. ljuí: Ed. Unijuí, 2004.

STRIEDER, R.; GIRARDI, A. Biologia do amar: pistas para recriar sensibilidade humana e ambiental. Revista Espaço Pedagógico, Passo Fundo, v. 26, n. I, p. 282-300, 2019. Disponível em: http://www.upf.br/seer/index.php/rep. Acesso em: 10 mar. 2020.

ZIZEK, S. Bem-vindo ao deserto do viral! Coronavírus e a reinvenção do comunismo. In: Dossiê Boitempo COVID-19. São Paulo: Boitempo, 2020. Disponível em: https://blogdaboitempo.com.br/dossies-tematicos/dossie-coronavirus/. Acesso em: 20 mai. 2020.

Recebido em: 14 de junho de 2020.

Versão corrigida recebida em: 10 de agosto de 2020.

Aceito em: 23 de setembro de 2020.

Publicado online em: 19 de março de 2021 .

Olhar de professor, Ponta Grossa, v. 24, p. I-19, e-I5980.01 I, 2021.

Disponível em <https://revistas2.uepg.br/index.php/olhardeprofessor> 